\author{
Y. Tur $^{1}$, Y. Pavlovskyi ${ }^{1}$, I. Virt ${ }^{1,2}$
}

\title{
Measurement of Thermoelectric Parameters of Thin-Film Semiconductor Materials Using the Harman Method
}

\author{
${ }^{1}$ Drohobych Ivan Franko State Pedagogical University, 82100 Drohobych, Ukraine, e-mail: tur2014@meta.ua \\ ${ }^{2}$ Rzeszow University, 1, Pigonia Str., 35310 Rzeszow, Poland, isvirt@email.ua
}

\begin{abstract}
For the analysis of the measurement of thermoelectric parameters of semiconductors, the Harman pulsed method was used. The authors propose a new approach to determine the thermoelectric quality factor of thin semiconductor films in the temperature interval $(300 \div 500) \mathrm{K}$ by directly measuring a series of electric circuit parameters. The theory of the method and its application in the measurement methodology are described in detail. The dependences of electrical quantities on the time, namely voltage $-\mathrm{V}(\mathrm{t})$, are investigated at different values of current pulses for thin films $\mathrm{PbTe}<\mathrm{Tl}>$ grown by the pulsed laser deposition.

Keywords: thin films, lead telluride, thermoelectric quality factor, the Harman method, pulsed-laser deposition.
\end{abstract}

Article acted received 01.08.2019; accepted for publication 15.09.2019.

\section{Introduction}

Thin-film semiconductor materials are of great interest for use in thermoelectric devices since they are able to increase the Seebeck coefficient $(S)$ and reduce the thermal conductivity $(k)$ of the films by nanostructuring the material. In particular, superlattice structures are studied to achieve an increase in $S$ and a decrease in $k$ without significant reduction of the electrical conductivity $(\sigma)$ of the material. These factors influence the thermoelectric quality factor $(Z T)$ [1].

The thermoelectric efficiency $Z=S^{2} \sigma / k$, where $S-$ is the Seebeck coefficient, $\sigma-$ is the specific electrical conductivity, $k-$ is the coefficient of thermal conductivity, is the most important characteristic of the thermoelectric material, which requires the most accurate definition. A standard average measurement error of individual parameters is about $5 \%$; then the average measurement error of $Z$ is $20 \%$. Therefore, for the measurement of Z, a special method [2] was developed, which allows measuring all these parameters on one sample in one measurement cycle, with the identical temperature differences being included in the calculation of $\mathrm{S}$ and $\mathrm{k}$ subject to same sample geometry. The total error of this technique is about $10 \%$.

It is the Harman method which is the most universal for measuring $Z[3,4]$. At the heart of the method lies the idea that, with a small current $I$ through sample of Joule heat, which is quadratic to $I$, can be neglected.
In this case, from the conditions of the thermal balance at the ends of the sample in adiabatic conditions, we can obtain the relation:

$$
Z T=\frac{U_{S}}{I R_{S}}-1
$$

where $U_{s}-$ is the voltage drop on the sample when current $I$ passes through it and $R_{s}-$ is the sample resistance. This method allows you to determine $Z T$ by measuring the voltage drop on a sample subject to constant and alternating current $-U_{-}=U_{s}$ i $U_{\sim}=I R_{s}$, respectively [5].

In fact, the requirement for adiabaticity is inappropriate because, when passing arbitrarily small current, this leads to the endless heating of the sample. Therefore, real conditions are never adiabatic, and this should be taken into account. In this case, $Z_{e f} T=\frac{U_{-}}{U_{\sim}}-1$ is measured instead of $Z$. The $Z_{e f}$ value at room temperature is $5-12 \%$ less than $Z$. Taking into account heat losses can significantly reduce this discrepancy, and the overall error of determination does not exceed $5 \%[6,7]$.

This method makes it possible to determine the quality of the material directly. The measurements are reduced to the determination of the potential difference $U_{\sim}$ on the contacts when passed through a sample the alternating current and the difference of the potentials $U_{-}$ 


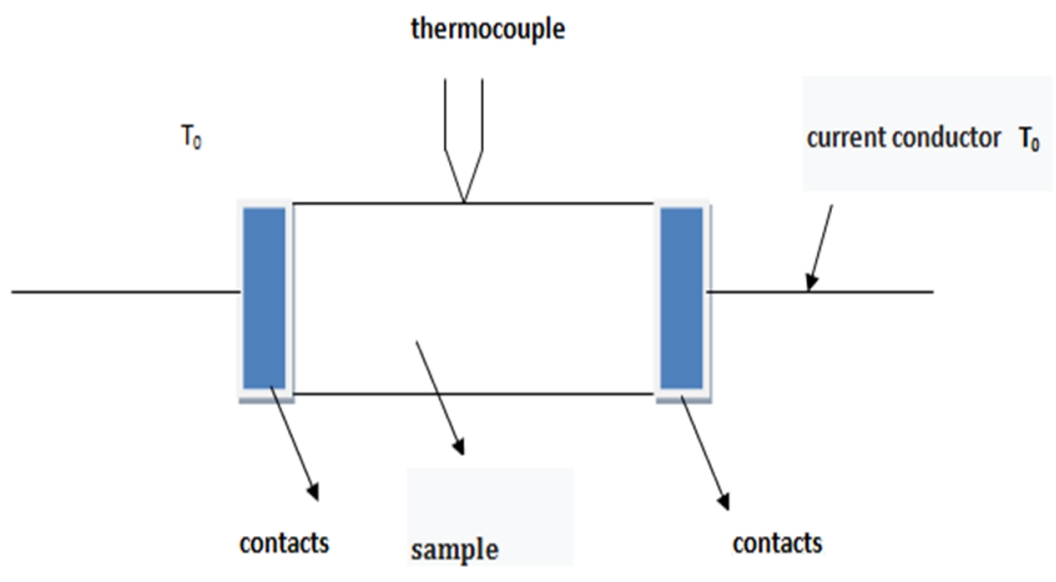

Fig. 1. The scheme of the Harman method.

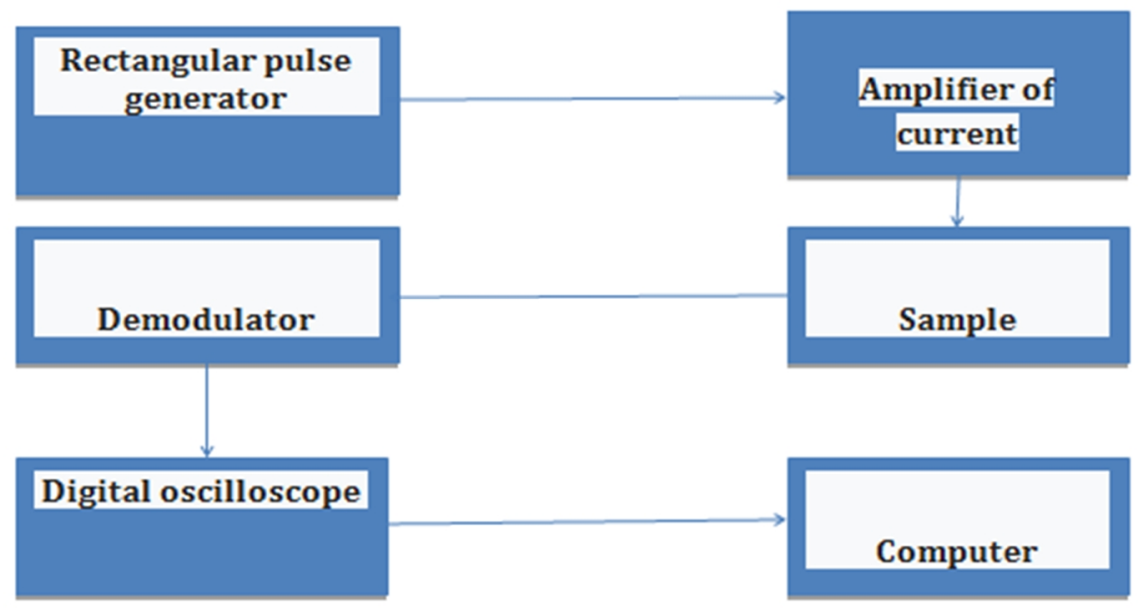

Fig. 2. Block-scheme/Flow-chart of the measuring unit.

when passed through a sample the direct current. For identical quantities of alternating and direct currents $I$ :

$$
Z=\frac{1}{T} \cdot \frac{U_{-}-U_{\sim}}{U_{\sim}},
$$

where $T-$ is the average temperature of the sample. In addition, the Harman method makes it possible to find the values of $\alpha, \sigma$ and $k$ on the same sample [8].

The coefficient of thermal EMF is determined from the formula:

$$
\alpha=\frac{U_{-}-U_{\sim}}{\Delta T},
$$

where $\Delta T$ is the temperature difference $T_{1}-T_{2}$ at the ends of the sample when passed of direct current. The conductivity of the sample material is determined from the expression

$$
\sigma=\frac{I_{\sim}}{U_{\sim}} \cdot \frac{l}{S},
$$

where $I_{\sim}-$ is the value of the alternating current, $l-$ is the length of the sample, $S-$ is its cross-section. The thermal conductivity of the material is determined from Fourier's law [9, 10].

$$
\kappa=\frac{\alpha I_{-}}{\Delta T} \cdot \frac{l}{S}
$$

\section{Experiment}

Samples of $\mathrm{PbTe}$ та $\mathrm{PbTe}<\mathrm{Tl}>$ were obtained by pulsed laser deposition (PLD) using stoichiometric targets. The targets were made of $\mathrm{Pb}, \mathrm{Te}$ and $\mathrm{Tl}$ elements having a purity of $5 \mathrm{~N}$ and placed in vacuum quartz ampoules for synthesis reaction. For deposition, YAG: $\mathrm{Nd}^{3+}$ laser was used with parameters: laser wavelength $1064 \mathrm{~nm}$, power peak in pulse $0.4 \mathrm{~J}$, power density $4 \times 10^{8} \mathrm{~W} / \mathrm{cm}^{2}$, pulse duration $10 \mathrm{~ns}$, pulse frequency 0.5 $\mathrm{Hz}$. The pressure inside the PLD chamber was $1 \cdot 10^{-5} \mathrm{~mm}$ $\mathrm{Hg}$, and the substrate temperature was $200^{\circ} \mathrm{C}$.

We used the Harman method as one of the techniques for measuring the thermoelectric parameters of semiconductor materials, which makes it possible to determine the thermoelectric quality factor. The analysis of the Harman method was carried out to determine other parameters of thin films in one experiment. The results are given of investigations of the voltage dependence on 
time with a certain value of the current pulse passing through the sample.

For the experiment, the studied $\mathrm{PbTe}<\mathrm{Tl}>$ sample deposited on glass substrates was placed in a thermostat on two conductors. Electric and thermal contacts were made on the ends of the sample to create its homogeneous thermal and electric field of the sample. In order for the Harman transition method to be exact, the following experimental conditions must be achieved: the adiabaticity of the device and the maximum constant temperature gradient for this current value. The scheme of the Harman method is presented in Fig. 1.

To calculate the parameters of the sample, the following geometrical dimensions were used: $t=5 \cdot 10^{-5} \mathrm{~cm}$ (thickness), $a=2 \cdot 10^{-1} \mathrm{~cm}$ (width), $l=$ $4 \cdot 10^{-1} \mathrm{~cm}$ (length of sample).

In fig. 2 shows the scheme of the measuring device based on the Harman method, modernized taking into account the achievements of modern measuring technology (stabilized DC and AC sources, the use of a computer for measuring operations and obtaining information about samples, etc.).

\section{Results and discussion}

In the research process, the following experimental conditions were achieved for the Harman method to be exact: the adiabaticity of the device and the maximum steady temperature gradient for the given magnitude of current $I$. The effect of the current magnitude on the thermoelectric properties is an important factor since the average temperature of the heat-release thermoelectric device can radically change according with the direction of $I$. In this case, the use of the smallest possible $I$ to achieve the desired values of the signal in the measurement of transient voltage will lead to the results that will reduce the impact of temperature dependence of $\Delta T$ and affect measurement accuracy.

The researched/tested samples of the corresponding geometric sizes were mounted in an isolated model of the measuring device by means of current contacts. The thin

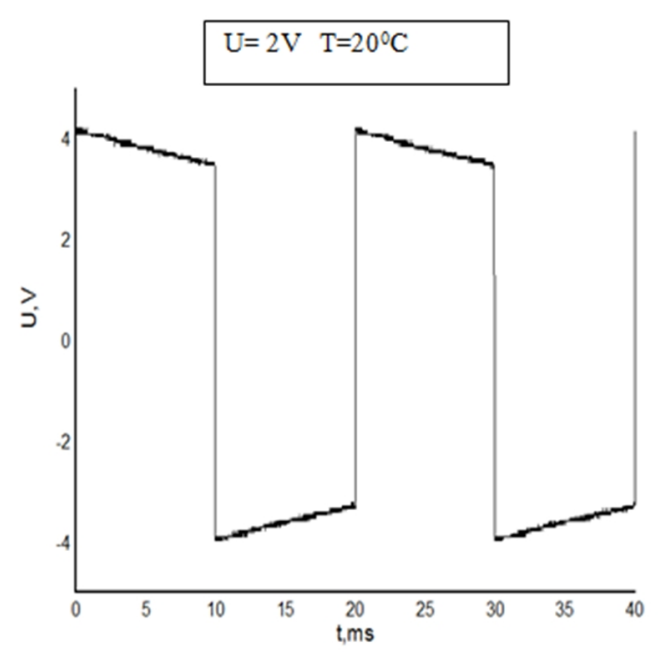

$\mathrm{a}$

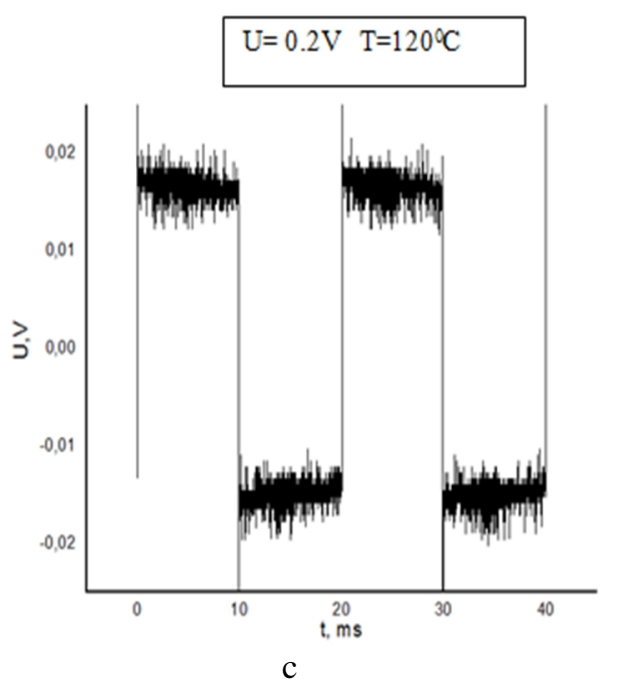

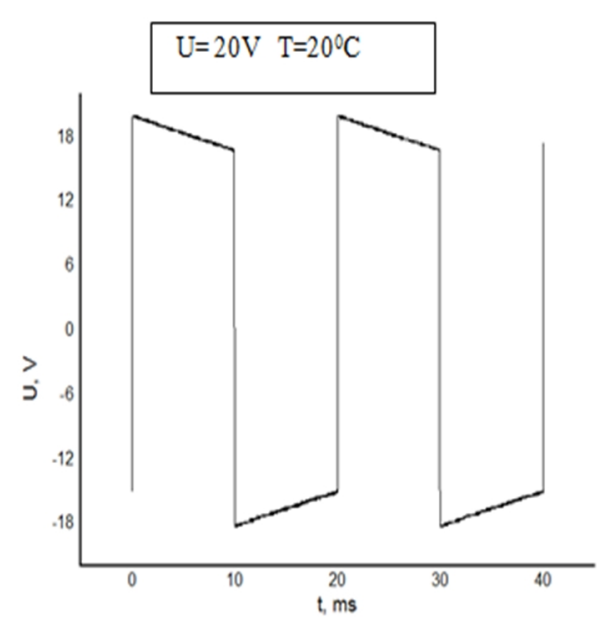

b

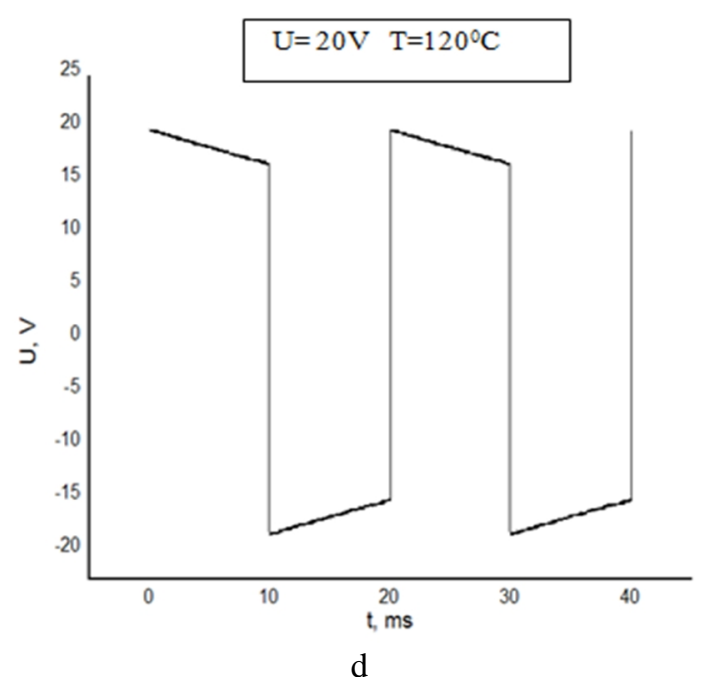

d

Fig. 3. Dependences of $\mathrm{V}(\mathrm{t})$ on time at different values of input pulses of current for a thin film $\mathrm{PbTe}\langle\mathrm{Tl}\rangle$ and different sample temperatures: a) $\mathrm{PbTe}<\mathrm{Tl}>-U=2 \mathrm{~V} ; T=20^{\circ} \mathrm{C}$; b) $\mathrm{PbTe}<\mathrm{Tl}>-U=20 \mathrm{~V} ; T=20^{\circ} \mathrm{C}$;

c) $\mathrm{PbTe}<\mathrm{Tl}>-U=0,2 \mathrm{~V} ; T=120^{\circ} \mathrm{C}$; d) $\mathrm{PbTe}<\mathrm{Tl}>-U=20 \mathrm{~V} ; T=120^{\circ} \mathrm{C}$. 


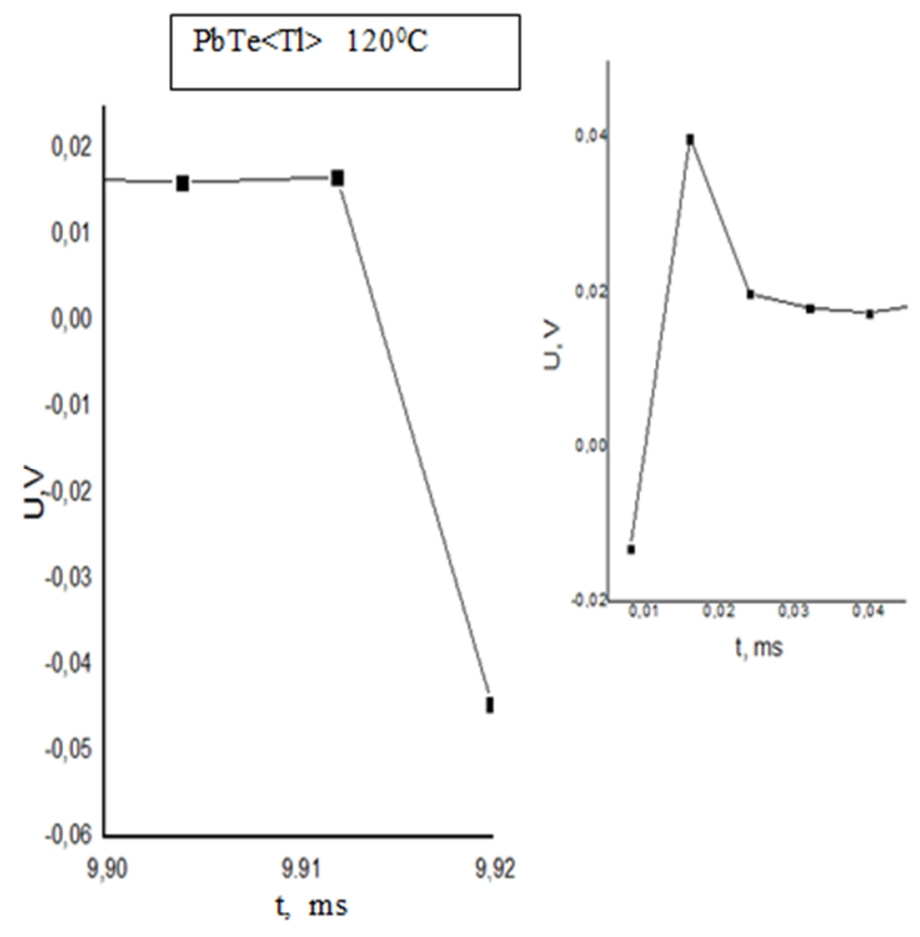

Fig. 4. Time dependence of the $\mathrm{V}_{\mathrm{S}}$ parameter at high resolution - pulse droop (on the tab - pulse increase) for the sample $\mathrm{PbTe}<\mathrm{Tl}>\left(\mathrm{U}=0.2 \mathrm{~V} ; \mathrm{T}=120^{\circ} \mathrm{C}\right)$.

films $\mathrm{PbTe}<\mathrm{Tl}>$ with an area of $10^{-3} \mathrm{~cm}^{2}$ were also checked for the dependence of the $Z T$ parameter on their size, which can be the result of non-adiabatic conditions of the device due to thermal leakage through to an electrical contact. To connect with the measuring devices two-wire electrical lines were used to supply current and measure the resulting voltages on the entire device proper.

Fig. 3 shows the time dependences of the voltage $V(t)$ at different values of the current pulse through an electric circle containing a measuring sample in the form of a thin film $\mathrm{PbTe}<\mathrm{Tl}>5 \cdot 10^{-5} \mathrm{~cm}$ thick with the area of $10^{-3} \mathrm{~cm}^{2}$. The magnitude of the pulse of the voltage from the generator of $10 \mathrm{~ms}$ duration was changed in the range of $0.2 \div 20 \mathrm{~V}$, which corresponds to the current value $0.2 \div 20 \mu \mathrm{A}$.

Measurement of $V_{R}$ at the pulse front was used to determine the electrical resistance of the thin films $\mathrm{PbTe}\langle\mathrm{Tl}\rangle$. This high-speed measurement of electrical resistance ensures that the generated thermoelectric voltages do not cause errors when measuring the resistance of a sample of thin films $\mathrm{PbTe}\langle\mathrm{Tl}\rangle$.

The timing values of the $V_{R}$ measurement of the device indicate that the relaxation of the electric field is achieved at about $10 \mu$ s after the droop on the edge of the current pulse. Fig. 4 shows the time dependence of the $V_{S}$ parameter at high resolution - pulse growth and decrease in semi-logarithmic coordinates for the sample
$\mathrm{PbTe}<\mathrm{Tl}\rangle$. An extrapolation of the curve was used to determine the value of $V_{S}$ at the edge of the curve $(\mathrm{t}=0)$.

By formula: $Z_{e f} T=\frac{U_{-}}{U_{\sim}}$ parameter $Z T$ was estimated which was $\approx 7$ giving the value of parameter $\mathrm{Z}$ $\approx 0.021 / \mathrm{K}$ for the operating temperature of $120^{\circ} \mathrm{C}$.

\section{Conclusions}

The carried out analysis of the Harman method as one of the most effective methods for measuring the thermoelectric parameters of thin-film semiconductors allowed to investigate the time dependencies of the passage of a current pulse in thin films $\mathrm{PbTe}<\mathrm{Tl}>$ under different values of the pulse current and different temperatures. From the time dependences of the electric field value, the $\mathrm{ZT}$ and $\mathrm{Z}$ parameters were determined, which were 7 and $0.021 / \mathrm{K}$ respectively for the working temperature of the film material $-120^{\circ} \mathrm{C}$.

Tur Y. - postgraduate;

Pavlovskyi Y. - Ph.D., Associate Professor, Associate Professor of the Department of Technological and Professional Education;

Wirt I. - Professor, Ph.D.

[1] B. Beltrán-Pitarch, J. Prado-Gonjal, A.V. Powell, J. García-Cañadas, Journal of Applied Physics 125(2), 025111 (2019) (doi.org/10.1063/1.5077071).

[2] L. Liang, X. Si-chao, L. Guang-hai, Chinese Journal of Chemical Physics 29(3), 365 (2016). (DOI: 10.1063/1674-0068/29/cjcp1509194). 
[3] A. Satake, H. Tanaka, T. Ohkawa, T. Fujii, I. Terasaki, Journal of Applied Physics 96(1), 931 (2004) (doi.org/10.1063/1.1753070).

[4] E.E. Castillo, C.L. Hapenciuc, T. Borca-Tasciuc, Review of Scientific Instruments 81(4), 044902 (2010) (doi.org/10.1063/1.3374120).

[5] B. Kwon, Seung-Hyub Baek, S. Keun Kim, Jin-Sang Kim, Review of Scientific Instruments 85(4), 045108 (2014) (doi.org/10.1063/1.487041).

[6] D. Olaya, Chien-Chih Tseng, Wen-Hao Chang, Wen-Pin Hsieh, Lain-Jong Li, Zhen-Yu Juang, Y. Hernández, Journal Flat Chem. 14(1), 100089 (2019) (https://doi.org/10.1016/j.flatc.2019.100089).

[7] Zhen-Yu Juang, Chien-Chih Tseng, Y. Shi, Wen-Pin Hsieh, S. Ryuzaki, N. Saito, Chia-En Hsiung, Wen-Hao Chang, Y. Hernandez, Y. Han, K. Tamada, Lain-Jong Li, Journal Nano Energy 38(3), 385 (2017) (doi:10.1016/j.nanoen.2017.06.004).

[8] J. de Boor, V. Schmidt, Applied Physics Letters 99(2), 022102 (2011) (doi:10.1063/1.3609325).

[9] T. Favaloro, A. Ziabari, J.-H. Bahk, P. Burke, H. Lu, J. Bowers, A. Gossard, Z. Bian, A. Shakouri, Applied Physics Letters 116(3), 034501 (2014) (doi: 10.1063/1.4885198).

[10] Y. Hasegawa, M. Otsuka, AIP Advances 8(2), 075222 (2018) ( doi.org/10.1063/1.5040181).

\title{
Ю.В. Тур ${ }^{1}$, Ю.В. Павловський ${ }^{1}$, І.С. Вірт ${ }^{1,2}$ \\ Вимірювання термоелектричних параметрів тонкоплівкових напівпровідникових матеріалів методом Хармана
}

\author{
${ }^{1}$ Дрогобицький державний педагогічний університет імені Івана Франка, 82100 Дрогобич, Украӥна, \\ e-mail: tur2014@meta.ua \\ ${ }^{2}$ Жешувський університет, 35310 Жемув, Польща, isvirt@email.ua
}

\begin{abstract}
Для аналізу вимірювання термоелектричних параметрів напівпровідників, використано імпульсний метод Хармана Запропоновано новий підхід для визначення термоелектричної добротності тонких напівпровідникових плівок в інтервалі температур $(300 \div 500) \mathrm{K}$ шляхом безпосереднього вимірювання ряду параметрів електричного кола. Детально описано теорію методу, застосування його у методиці вимірювань. Досліджено залежності електричних величин, зокрема напруги - V(t), від часу при різних значеннях імпульсів струму для тонких плівок $\mathrm{PbTe}<\mathrm{Tl}>$, вирощених імпульсним лазерним осадженням.

Ключові слова: тонкі плівки, телурид свинцю, термоелектрична добротність, метод Хармана, імпульсно-лазерне осадження.
\end{abstract}

